\title{
Admission to Higher Education: Difficulties felt. How to fight them?
}

\author{
Vasconcelos, Rosa M. \\ President of Pedagogical Council of the School of \\ Engineering of University of Minho \\ Guimarães, Portugal \\ rosa@,det.uminho.pt
}

\author{
Pinheiro, Magda 0. \\ Pedagogical Council of the School of Engineering \\ of University of Minho \\ Guimarães, Portugal \\ magda@eng.uminho.pt
}

\author{
Amaral, Luís \\ Department of Information Systems \\ School of Engineering of University of Minho \\ Guimarães, Portugal \\ amaral@dsi.uminho.pt
}

\begin{abstract}
The School of Engineering of the University of Minho (EEUM), aiming at improving the quality of Higher Education (HE), has been adapting to the new demands and realities. Bologna Process brought a number of challenges to higher education institutions, notably in teaching, learning and assessment [1, 2].

Based on needs identified by students, such as autonomy management and student responsibility in their education, continuous evaluation, associated to the promotion, empowerment and facilitation of professional development and the active role of the student in the evaluation process [3], the EEUM sought to respond with direct actions for students. In 2006/2007, a study was carried out on writing skills in university students, diagnosing difficulties in textual comprehension, which is reflected in the expression and transmission of the intended message [4].

Thus, since 2004, EEUM has developed training actions for students that address: (1) new requirements inherent to the transition to Higher Education; (2) self-regulation of learning; and (3) teamwork. In 2006, three training modules were added, namely (4) writing skills; (5) bibliographic research; (6) oral skills.

During these ten years, Steering Committees of each course of the School were given the option to opt for the various training modules or only for some more specific ones. Thus, over 1000 hours of contact with the students were taught in the 12 years of the EEUM. These actions are taught grossly in the 1 st year of the Study Plan. However, there are some more focused on the 3rd and the 5th years.

At the end of each training course, students respond to an inquiry with a few closed questions and three open questions, namely "Aspects I considered most positive in training", "Aspects I considered less positive in training" and "Suggestions and comments". This article presents a content analysis of the open answers of students at the end of the training. This type of analysis allows us to understand student's opinions and a more
\end{abstract}

introspective feedback of actions. Concerning positive points, students highlight the contents covered in general, followed by the relationship between trainer and trainees, work preparation, time management and content presentation in a clear way. Concerning less positive points, students focused on the duration of the session, much information for a short time, asked for more practical and specific examples and too much time between the sessions. For suggestions and comments, although many students do not make any mention, there are many positive reinforcements to the training in general, the initiative, the more dynamic approach in the integration of the new students and the contents, there are also references to the duration, evidencing that they should be shorter sessions.

This analysis is essential take stock of ten years of training at the EEUM, the impact it had and has on students and what can be adjusted to promote the improvement of teaching and learning in engineering and technology.

Keywords-Higher Education; active role of the student; selfregulation of learning; teamwork; writing skills; oral skills.

\section{INTRODUCTION}

Higher Education in Portugal has adapted to the demands and challenges of the Bologna Declaration. Thus, the University of Minho restructured and reorganized all its courses, affecting the teaching degrees, the curricular contents and the very concept of teaching and learning, with innovative methodologies and pedagogical practices $[2,5,6]$.

Currently, the Engineering courses of the Engineering School of the University of Minho are all Integrated Studies Cycle, that is, the course encompasses the 1st and 2nd cycles of studies, making up $300 \mathrm{ECTS}$, thus conferring the master's degree in end of the course. The courses are organized in five 
academic years and each academic year comprises mostly semester and some annual curricular units [7].

\section{COURSE OF PROJECT}

Faced with the challenge of implementing the Bologna Process in the adaptation of Higher Education courses, the School of Engineering adopted the teaching / learning model according to the Teaching by Design methodology.

Teaching by Project "is an alternative teaching / learning methodology that seeks to provide an effective solution to the current problems and challenges of education".

Teaching by Design was initially developed at the University of Twente, in the Netherlands, where learning was sought through problem solving [8]. In this way, the students were involved in real or possible problems of the professional activity, motivating them to make a connection between theory and practice and an application of the most theoretical knowledge, giving a new meaning to learning in Higher Education [4].

According to Guedes et al. [9] "The methodology of learning by Project is related to an interdisciplinary and even transdisciplinary view of knowledge. Focusing on problem solving introduces a dynamic of integration and synthesis between theory and practice, tailoring it to the identification of relevant problems and building tailored solutions. "

As an extremely active teaching-learning methodology, teachers have to constantly adapt to new challenges and problems, as well as to study and validate the solutions adopted by working groups.

The Projects are included in a semester course, where the students have to include all the knowledge acquired in the course subjects.

Based on this paradigm, this study analyzes the role of the tutor in the development of critical thinking and problem solving in that context, as well as the inherent "class relations" between tutor-student and student-student.

The main objective of Teaching by Project is to create learning conditions, operational domain and integrated application of the learning outcomes of the curricular units that integrate the Project.

\section{SOFT SKILLS}

The Teaching by Project methodology fosters the active role of the student in his learning. The student at the end of his / her academic year must be able to learn for himself any subjects that he / she understands that he needs to know or master throughout his professional life.

In this way, learning by Project is an open process, where the curiosity, creativity and commitment of the students determines the level of final results and the course of thought and work.

Teaching by Design values transversal competences. The value of knowledge reached is important, but "knowing to be", "knowing to be", "knowing to interact", "knowing to communicate", "knowing how to organize" and, finally, are fundamental.

It is called Soft skills personal attributes of each individual, as well as personality traits, social skills and communication. All the characteristics are evaluated so that a good income is obtained within a certain position.

Soft skills characterize how an individual interacts with peers within and outside the work environment. Unlike the socalled hard skills, soft skills involve emotions and intuitions, both of which are responsible for expressing and interpreting another person's feelings.

Thus, Higher Education intends to foster in its students beyond knowledge proactive and entrepreneurial behaviors in order to provide answers to complex questions of the job market. Graduates should excel through a diversity of skills, building an open and flexible mind to uncertain and volatile market imperatives.

Because they are not simple skills to be taught and learned, they are also difficult to quantify and classify: how to assess a person's capacity for empathy? Soft skills are subjective, but important for day-to-day life within a company's environment.

\section{DifFICULTIES DIAGNOSED}

The integration and success of students as well as their transition to the job market are a concern of the School of Engineering. Thus, several studies were carried out to understand the needs and difficulties of integration of the new students in the institution.

According to Freitas, Martins and Vasconcelos [3], many students reported problems of adaptation to higher education and the academic context, and a study was carried out to identify their problems, difficulties and constraints regarding adaptation to this new context $[4,11]$.

The results presented in this study denoted students' poor preparation for entry into higher education, poor motivation and commitment in the course, and ineffectiveness of existing support in adapting students to the new challenges and requirements of higher education.

Believing that it is possible to contribute intentionally to the development of the university student, particularly in the first year of the curriculum [10], and having diagnosed gaps in the methods of study, teamwork, strategies of learning regulation, a set of training modules for first year students was implemented [3].

\section{TRAINING ACTIONS DEVELOPED BY THE SCHOOL OF ENGINEERING}

According to Araújo et al. [12], the quality of the adaptation and success in Higher Education is related to previous characteristics of the students, and the literature suggests differences of gender, types of studies and familiar background in the students' results. In addition to sociocultural variables in this determination, more sociocognitive variables such as outcome expectations and self-efficacy seem to influence students' adaptive experiences. 
Some of the difficulties diagnosed in students entering Higher Education are the management of activities and time, personal autonomy, self-regulation and academic motivation, in some cases leaving the parents' home are also a challenge of autonomy in life management everyday life [4, 23].

Thus, in order to overcome academic difficulties, difficulties of social integration and difficulties of autonomy, training modules were implemented for the first year students of the School of Engineering, namely, (1) the new requirements inherent in the transition to Teaching Higher; (2) self-regulation of learning; (3) teamwork; (4) writing skills; (5) bibliographic research; and (6) oral skills.

The training actions developed by the Pedagogical Council of the Engineering School aim at a more adequate integration for a social and academic adaptation.

In the module "new requirements inherent to the transition to Higher Education", the themes on the Bologna process and its implications are worked on, as well as the students' involvement and responsibility for their own learning, aiming to identify the changes and new requirements inherent in the transition for higher education and to identify the implications of the Bologna process on learning (emphasis on active learning by the student).

The module "self-regulation of learning" focuses on the concept of self-regulation and its relation to learning, the definition of a work plan and time management. Its objectives are to identify the implications of the concept of self-regulation in the learning process; be able to plan, develop and evaluate a study plan; and develop time management strategies.

"Teamwork" aims to explain that the main characteristic of a team is cohesion, where the group is more important than the individual members. The topics covered are that all members of the group are responsible for the results, all members know the work of colleagues, communication must be constructive as a basis for reflection and mention formal aspects of work.

At the level of "writing skills", the module clarifies the systematization of ideas, the extraction of conclusions, the critical spirit and the bibliographical references. The intended learning outcomes are for students to develop the ability to write and synthesize academic documents, promote the ability to draw conclusions and prepare a list of questions, and know the steps involved in writing and writing an academic paper.

The "bibliographic research" module deals with bibliographic research and report writing, aiming at students being able to search, select, organize and interpret information accurately, as well as being able to correctly reference sources of information.

As for the "orality skills", students are working on how to perform a presentation, namely the placement of voice, posture and visual support to be adopted. It also addresses the systematization of ideas, the extraction of conclusions and the promotion of the critical spirit. The expected learning outcomes are the ability to systematize and discuss themes in open sessions, the making of future presentations with more success, and the awareness and appropriateness of behaviors in future formal contexts.

\section{Methodology}

All the students who attended the training courses of the Engineering School of the University of Minho conducted a questionnaire survey at the end of the sessions. Thus, the results of the surveys were analyzed to understand if the training actions implemented by the School of Engineering of the University of Minho were having the expected effect in the response to the needs felt in the past by the students. The survey consists of sixteen closed answers and three open answers, these answers being the subject of this article.

It was intended to understand through the inference and interpretation of the answers obtained if, the training actions are adequate to the needs of the students or if they need some readjustment.

Thus, through the analysis of content was intended to describe the most incisive and regular answers to the questions "Aspects that I considered more positive in training", "Aspects I considered less positive in training" and "Suggestions and comments." This type of analysis makes it possible to perceive students' opinions and more introspective feedback of actions.

The questionnaire survey has advantages over other techniques, but also certain limitations. In relation to the advantages, we can consider the same relatively economic. At the time of data collection the researcher does not influence the respondent, anonymity remains, it allows large samples (although the representability is never absolute given that it is always limited by a margin intervention practices and development of physical activities of error).

As limitations, we have the rigid ordering of the questions, being the answers of content and depth of the information relatively limited, being given answers with intention to please to the inquirer, sometimes of unconscious way, the credibility of the questionnaire is weak and hardly the causal relations are demonstrated. Often respondents do not respond to open-ended questions, such as "Positive aspects of training", "Things I considered to be less positive in training" and "Suggestions and comments".

\section{RESULTS ANALYSIS}

The data collection instrument used was the questionnaire survey consisting of open and closed questions.

However, only open answers will be presented and analyzed. There were 413 surveys, but the volume of responses is much lower, with very missing.

Thus, for the question "Aspects that I considered to be the most positive in the training", the respondents emphasized the content covered, relationship between trainer and trainees the elaboration of works, time management, presentation of contents in a clear way, and training in general, respectively.

The order of answers presented was faithful to the incidence and occurrence of the same in the questionnaires (Table 1). 

TRAINING"

\begin{tabular}{|l|c|}
\hline Responses & Incidence \\
\hline Content covered & 116 \\
\hline $\begin{array}{l}\text { Relationship between trainer and } \\
\text { trainees }\end{array}$ & 51 \\
\hline Elaboration of works & 43 \\
\hline Time management & 25 \\
\hline $\begin{array}{l}\text { Presentation of contents in a } \\
\text { clear way }\end{array}$ & 25 \\
\hline Training in general & 14 \\
\hline Missing & 68 \\
\hline
\end{tabular}

As for the "Aspects I considered less positive in training", the students focused on the duration of the session, much information for a short time, asked for even more practical and specific examples and too much time between the formations (Table 2).

TABLE II. "ASPECTS I CONSIDERED TO BE THE LESS POSITIVE IN THE TRAINING"

\begin{tabular}{|l|c|}
\hline Responses & Incidence \\
\hline Duration of the session & 122 \\
\hline $\begin{array}{l}\text { Much information for a short } \\
\text { time }\end{array}$ & 12 \\
\hline $\begin{array}{l}\text { More practical and specific } \\
\text { examples and too much time } \\
\text { between the formations }\end{array}$ & 8 \\
\hline $\begin{array}{l}\text { too much time between the } \\
\text { formations }\end{array}$ & 4 \\
\hline Missing & 236 \\
\hline
\end{tabular}

At the level of suggestions and comments, although many students make no mention. There are quite a few positive reinforcements to training in general; the initiative; the most dynamic approach in integrating new learners and content; there are also references to duration, evidencing that there should be more sessions with shorter duration; that training actions should be carried out by parties; in bigger quantity; and the reinforcement to continue to carry out training actions.

\section{VIII.CONCLUSION}

This article intends to understand the impact that the training actions of the Engineering School of the University of Minho have on the academic life of the students and if they facilitate the academic adaptation and benefit from the interventions of improvement in the study skills and selfefficacy. It was tried to understand if these actions helped to overcome the difficulties diagnosed in the past.

We can see from the open survey responses that students value these actions, but that they need to be reformulated, namely at the level of duration and number of sessions.

Thus, before the analysis of the most positive aspects, the less positive aspects, and the suggestions and comments of the students, the training actions of the Engineering School of the
University of Minho, the training sessions will be reformulated, being integrated in the scope of Integration 4.0. This integration is based on the voluntary action of the students at the time of registration.

Students will have some schedules available as well as training actions so that they can enroll themselves through the needs they deem most relevant at the time. The duration of the actions will be shortened to two hours modules, as mentioned in the suggestions and given as less positive aspect actions with three or four hours.

\section{ACKNOWLEDGMENT}

This work was partly funded by FEDER funds through the Operational Competitiveness Program (COMPETE) and by FCT with the projects PEst-C/CTM/UI0264/2015 and FCOMP- 01-0124-FEDER-022674.

\section{REFERENCES}

[1] J. V. Simão, S. M. Santos, and A. A. Costa, Ensino superior: uma visão para a próxima década, Gradiva Publicações Lda., 2003.

[2] J. V. Simão, S. M. Santos, and A. A. Costa, Ambição para a Excelência A oportunidade de Bolonha, Gradiva Publicações Lda., 2005.

[3] A. Freitas, J. Martins, and R. Vasconcelos, "Integração do(a)s Aluno(a)s do $1^{\circ}$ ano na Universidade do Minho", in Revista Galego-Portuguesa de Psicoloxía e Edcucacíon, n. ${ }^{\circ}$ 8, vol. 10, 2003, pp. 1373-1382.

[4] R. Vasconcelos, S. Monteiro, and M. Pinheiro, "Competências de escrita em alunos universitários", in World Congress on Communication and Arts (WCCA), 2007, pp. 75-78.

[5] J. V. Simão, Modernização do ensino superior da ruptura à excelência, Fundação das Universidades Portuguesas, 2003.

[6] MCTES, " Reforma do Sistema de Ensino Superior Português", Relatório de 2 anos de progresso, como submetido à OCDE, 2008, p.1. Acedido em 29 de Setembro, através de: http://www.mctes.pt/archive/doc/Sum_Executivo_Relatorio_Pogresso OCDE rev25nov08.pdf

[7] Universidade do Minho, "Relatório de concretização do processo de Bolonha na Universidade do Minho," Universidade do Minho, Braga, 2008.

[8] N. van Hattum-Janssen and R. M. Vasconcelos, "The role of the tutor in Project-Led Education: the developmente of an evaluation instrument," INTERTECH, pp. 27-31, 2008.

[9] M. G. Guedes, J. M. Lourenço, A. I. Filipe, L. Almeida, and M. Alfredo Moreira, "Bolonha Ensino e Aprendizagem por Projeto", V. N. de Famalicão: Centro Atlântico, Lda., 2007.

[10] Perry, "Forms of Intellectual and Ethical Development in the College years: a scheme," in L. Santos, "Adaptação Académica e Rendimento Escolar: Estudo com alunos do 1. ano", Grupo de Missão para a Qualidade do Ensino/Aprendizagem: Braga, 2001.

[11] L. S. Almeida, E. M. Fernandes, A. P. Soares, R. Vasconcelos and A. Freitas, "Envolvimento académico: confronto de expectativas e comportamentos em universitários do $1^{\circ}$ ano", Revista Psicologia e Educação, Universidade da Beira Interior, 2003.

[12] A. M. Araújo, A. A. Santos, A. P. Noronha, C. Zanon, J. A. Ferreira, J. Casanova and L. S. Almeida, "Dificuldades antecipadas de adaptação ao ensino superior: um estudo com alunos do primeiro ano", in Revista Galego-Portuguesa de Psicoloxía e Educacíon, vol. 3, 2016, pp. 102111. 